\title{
Impact of Resin Tapping on Income Generation and Forest Condition in Janajagirti Community Forest, Sahajpur-3, Kailali District, Nepal
}

\author{
Ramchandra Awasthi $^{1}$, Deepak Gautam ${ }^{1,2^{*}}$, Garima Sharma ${ }^{1}$, Catherine Mhae B. Jandug ${ }^{2,3}$, Vijay \\ Kumar Yadav ${ }^{1}$
}

${ }^{1}$ Institute of Forestry, Tribhuvan University, Nepal

${ }^{2}$ Collage of Forestry, Beijing Forestry University, Beijing 100083, China

${ }^{3}$ College of Forestry and Environmental Science, Caraga State University, Philippines

\section{*Corresponding Author}

Deepak Gautam

\section{Article History}

Received: 19.02 .2020

Accepted: 26.02 .2020

Published: 14.03.2020

\begin{abstract}
Resin, one of the important non-timber forest products, is collected from Pinus roxburghii commonly known as Khote Salla. Resin tapping practice in Nepal is gaining high momentum in recent days and majority of industries are working to collect resin from different areas of Nepal and has significantly resulted in bringing changes in livelihood assets of people. Key informant interview $(n=3)$, focus group discussion $(n=3)$ and household survey $(n=21)$ were undertaken to access impact of Resin Tapping on income generation of the households as well as CF and impact on forest condition by comparison between the processes mentioned in the Resin Tapping Guideline, 2064 and the actual practices. This study reveals that resin tapping operation has not any contribution on income of individual for their livelihood up-liftment of the community but the CFUG as a whole is dependent on Resin tapping and scientific forest management activities. Unscientific resin tapping operation has been carried out and maximum activities were beyond the guideline that has negative impact on forest. Only a single person of the community is involved in this operation as a supervisor so, the wage rate must be given more consideration to attract the locals. Timely Monitoring and supervision is important to stop the unscientific resin tapping operation.
\end{abstract}

Keywords: Community Forest, Livelihood, Pinus roxburghii, Resin Tapping, Impact.

\section{INTRODUCTION}

Pine resin is one of the valuable plant extracts which is popularly tapped from 12 different pine tree species [1] around the world however in Nepal resin could be extracted from Chir pine (Pinus roxburghii) and Blue pine (Pinus wallichiana). Only Chir pine can be tapped economically which is widely distributed in mid hills of Nepal in the elevation of 900-1950 meter and sometimes up to 2700 meter [2]. Blue pines, which occur at higher altitudes and yield only about 1 kilogram annually per tree, are therefore usually not profitable to tap. A Chir pine tree yields about 3 to 6 kilograms resin annually. Pinus roxburghii has the fourth highest position in term of total growing stock and identified as the major forest type in Nepalese forest classification [3]. The resin tapping activities has been handed over to Community Forests after the implementation of Master Plan of the forestry sector [4]. Resin tapping in Nepal was initiated in 1986. It has been started in 34 district of Nepal [2]. Resin collection only could be a viable source of income for the local people and revenue for the nation and CFUGs [5] however it needs carefully regulated tapping intensity. Local people are employed in the activities of resin tapping and thus having income generation and thus help in support of their livelihood [6]. In Nepal it is estimated that about 10,000 people are involving in the resin tapping work and people can earn up to $30,000 /$ head in eight month of tapping period [7].

The local people will have great employment opportunities thereby improving the socio-economic status of the forest dwellers [8]. In the hills, CF is of prime importance for the restoration of forest resources and poverty reduction to improve the livelihoods of the rural poor [9]. Rosin and Turpentine industries are playing crucial role creating job

Copyright @ 2020: This is an open-access article distributed under the terms of the Creative Commons Attribution license which permits unrestricted use, distribution, and reproduction in any medium for non commercial use (NonCommercial, or CC-BY-NC) provided the original author and source are credited. 
opportunity for rural people. It is also major income sources of community forest user group [10]. This study focuses on investigating whether the role of resin collection has been beneficial to both forest and local people or whether it is actively involved in degrading the condition of forest and investigate whether the resin tapping processes is being operated following the norms of Resin Tapping Guideline, 2064 or not.

\section{Materials ANd Methods \\ Study Area}

The study was carried out in 'Shree Janajagirti Community Forest' of Kailali district. This community forest is surrounded by Salghari CF in east, Ningaladi Danda in the west, Thulo Khola in the north and Thula Gairako Danda in the south. This community forest lies in Chure.-3, Sahajpur which is at $58 \mathrm{~km}$ North to Dhangadhi (headquarter). It is geographically located at $29^{\circ} \mathrm{N}$ to $81^{\circ} \mathrm{E}$. The total geographical coverage of the forest is 431.15 ha. It is situated at the altitude of $205 \mathrm{~m}-1950 \mathrm{~m}$ above the sea level. It is of mixed forest type and consists of Pine forest in combination with Broad leaf. Major plant species documented in this area are: Pinus roxburghii, Pinus wallichiana, Castanopsis species, Quercus species, and Schima wallichii, Rhododendron species etc. This Community Forest is privileged of wild fauna like Leopard, Wild Boar, Deer, Fox, Monkey, and Rabbit etc.

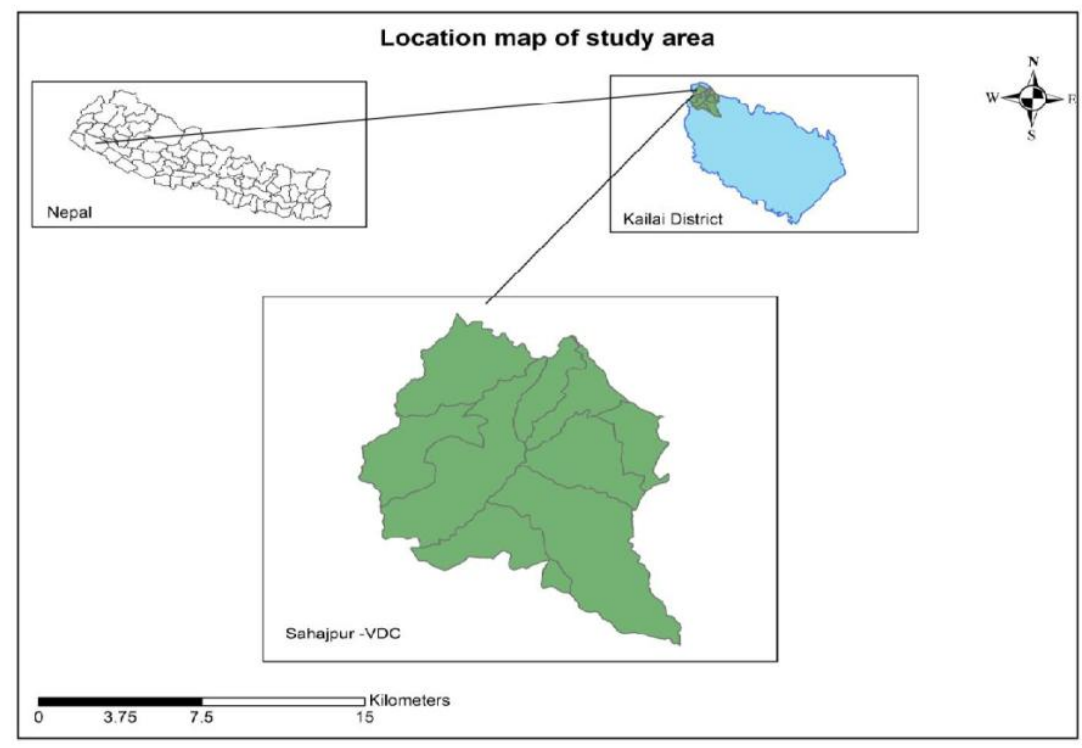

Fig-1: Map of the Study Area

\section{Data Collection and Analysis}

The sample size (n) for the questionnaire survey was determined by using the following formula given by Arkin and Colton [11] cited in Dongol [9] at 95\% confidence level.

Sample size $(\mathrm{n})=\left[\mathrm{N}^{*} \mathrm{z}^{\wedge} 2 * \mathrm{P}(1-\mathrm{P})\right] /\left[\mathrm{N}^{*} \mathrm{~d}^{\wedge} 2+\mathrm{z}^{\wedge} 2 * \mathrm{P}(1-\mathrm{P})\right]$

Where, $\mathrm{N}=$ Total number of households

$\mathrm{Z}=$ value of standard variant at $95 \%$ confidence level (1.96)

$\mathrm{P}=$ estimated population proportion $(0.05)$

$\mathrm{d}=$ error limit of $5 \%(0.05)$

Total no. of households $=207$

No. of households taken as sample $=21$ i.e. $10 \%$ of the total households

Direct observation was conducted of the site for cross checking the information collected from discussion and other sources. Key informant interviews $(n=3)$ were conducted with the company personnel and the executive committee members of the CF to present their views on the current and past earning of Community forest and the difference between past and present economic condition of local people. The group discussion $(n=3)$ was carried out with AFO's, Rangers, entrepreneurs and staffs of rosin and turpentine industries to access contribution of resin on economic condition of local people to enhance their livelihood. Also, to access whether it has negative or positive impact on forest.

Stratified systematic sampling prescribed by community forestry inventory guideline was applied during the inventory process. The total forest area of the CF was divided into 10 compartments (OP, 075/084). This study was confined in compartment-C1S5, which has maximum number of pine trees as per the record. 
No. of sample plots $=5$

Sampling intensity $=0.5 \%$ (as per the inventory guideline)

Area of a sample plot $=500$ sq. $\mathrm{m}$ (Circular plots were used)

\section{RESUlT AND DisCUSSION}

Socio-economic aspects of respondents: From our study we got to know that among the 21 households surveyed $53 \%$ of the respondents were female and only $47 \%$ of the respondents were male. Also, $57 \%$ of the respondents were literate whereas $43 \%$ of them were illiterate. The major ethnic population found was Chhetri followed by Brahmin, Tamang, Magar and Dalit. Majority of the population were involved in agriculture but no one was involved in resin tapping operation. But the study revealed that Janajagirti CFUG had no other income generating source except the income from resin selling before the Scientific Forest Management activities. $70 \%$ of the total fund is from Scientific Forest management and 30\% from Resin tapping.

Income of CFUG from Resin: The income in year 073/074 was Rs.115600 at the royalty of Rs. 8.5/kg. Similarly, the income of year 074/075 was Rs. 122400 with the rate of Rs. 9/kg and the year 075/076 is Rs. 163200 with the rate of Rs. $12 / \mathrm{kg}$. An increasing rate in the income was seen in the last three years which may be due to the increase in royalty. (Source: Subdivision office, Sahajpur). Though the respondents were not involved in the resin tapping work, this data can be used to figure out the contribution of income from resin tapping which is flowing out from the CFUG. As per the wages earned by different categories of respondents involved in different activities of resin tapping, it was found that people involved in collecting had an average income of Rs. 229500 per season. Similarly, those involved in loading and unloading was given Rs. 50 per tin and the yearly income was dependent on the amount of tin collected. Mates are the person who is involved in bringing labors from other places (commonly called Thekdars) but local people were not involved in collection. (Exchange rate 1 US dollor $=$ NRs 115)

Contribution of CFUG Fund Generation: This CF was found to be totally dependent on the fund generated from resin so the following contribution could be concluded as the contribution of resin tapping on CFUG. The CFUG had been organizing various skill developing workshops, trainings and also the livelihood upliftment programs. There are several income generating program for poverty elevation (1) Training for Apiculture and subsidy for buying improved hives. (2) Training for off seasonal vegetable farming. (3) Skill development workshops (4) Improved or modern animal husbandry. Similarly, few development works from the contribution of resin are: (1) Constructed CFUG's building (1) Agriculture road Construction. (3) Donation for School.

Impact on forest condition: Inventory was done in compartment-C1S5 where there was maximum abundance of pine trees. Systematic sampling was used using $0.5 \%$ sampling intensity. Inventory was done in 5 circular plots. The growing stock in year 2075 was $213 \mathrm{cu}$. m per ha. It was found to be increasing and reached $243 \mathrm{cu}$. $\mathrm{m}$ in the year 2076. [Source: OP (2075) Field survey, 2019].The number of regeneration per ha in the year 069/073 was 4772 which was reduced to number 4190 in the year 075 . The decrease in the number might be due to resin tapping operation but it is not fixed reason for the decrease in the number of regeneration as various other factors also affect it. The number of sapling in the year 069/073 was 958 per ha which was also decreased to 540 in the year 075. [Source: OP (069/073), OP (2075) Field survey, 2019]

Condition of the trees based on resin tapping operation: Among the trees sampled, $57 \%$ of the trees were found be good with proper tapping. $9 \%$ of the trees were tapped even they were on the sloppy land- The resin tapping guideline, 2064 has strictly prohibited to tap the trees which lies on the sloppy land. $18 \%$ of the trees were found to be improperly tapped. The guideline, 2064 has mentioned certain tapping rule (i) The rill must be $32 \times 32$ (ii) Single cone should be used and single blaze should be made per tree/season (iii) Trees less than $30 \mathrm{~cm}$ are not allowed to tap. $6 \%$ of the trees were hampered due to the extraction of Diyalo. Diyalo is actually a type of torch light which is used by the villagers from the stem of Khote Salla as it is highly flammable. $10 \%$ of the trees were found to be dead and dried.

Perception of Community Households: From the study about perception of community household on contribution of resin tapping in community development we got to know that among the total households, $43 \%$ of the people were satisfied with the fund expenses in different community development activities which was generated by CFUG from resin tapping, 50\% of the people were neutral and only $7 \%$ of the people were dissatisfied. Also according to our study, among the households, majority of the people were in the favor of continuing the resin tapping operation in their Community forest i.e. $65 \%$ of the households. $14 \%$ of the people were not interested in this field and $21 \%$ of the people were against the favor of this activity. From our study it is also found that norms of Resin tapping guideline, 2064 was not followed in many trees during the resin tapping operation. The guideline, 2064 has mentioned certain tapping rule. The rill must be $32 \times 32$. Single cone should be used and single blaze should be made per tree/season. Trees less than $30 \mathrm{~cm}$ are not allowed to tap. Unscientific Resin tapping operation has caused heavy tapping and dehydration in the blaze 
area due to the use of highly concentrated acid as stimulant. The wage rate for labor on trees marking, resin tapping and transportation to depots is very low.

\section{CONCLUSION}

From our study we can conclude that resin tapping operation has not any contribution on income of individual households but the CFUG as a whole is dependent on resin tapping and Scientific Forest Management program. Norms of Resin tapping guideline, 2064 was not followed in many trees during the RT operation. Unscientific Resin tapping operation has caused heavy tapping and dehydration in the blaze area due to the use of highly concentrated acid as stimulant. Carelessness of stakeholders and lack of proper supervision has led to death of tree due to the extraction for Diyalo.

\section{ACKNOWLEDGMENTS}

We are thankful to Janajagirti Community Forest Users Group for their response and cooperation during my field work and to Division Forest Office, Kailali and Sub-Division Forest office Sahajpur for providing me all the necessary documents. Our sincere gratitude to Ministry of Industry, Tourism, Forest and Environment Sudurpaschim province for financial support. Our thanks also go to Sooraj Bhatt, Roshan Thagunna, Supuspa Regmi, Arjun Bhusal, Suresh Paudel for their support.

\section{REFERENCES}

1. Coppen, J. J. and Hone, G. A. (1995). Gum naval stores: Turpentine and rosin from pine Organization of the United Nations, Rome, www. Gum naval stores/Turpentine and rosin from pine resin.

2. Jackson, J.K. (1994). Manual of afforestation in Nepal, Volume 2. Kathmandu: Forest Research and Survey Center, 2nd edition

3. DFRS. (1999). National forest inventory report: Department of forest research and survey, Ministry of forest and soil conservation, Kathmandu, Nepal.

4. Karki, I.S., \& Tiwari, S. (1998). Proceeding of the Fourth National Workshop on Community Forestry held in Kathmandu, Nepal, 4-6 August, 2004. Community Forest Division, Department of Forest.

5. Kanel, K. R. (2004). 25 years of community forestry in Nepal: Contribution to Millenium Development Goal. In K. R. Kanel, \&. (Ed.), 25 years of Community Forestry in Nepal (1-16). Community Forestry Division/Department of Forest/Government of Nepal

6. Acharya, H. (2005). Economic Analysis of Resin Tapping in Community Forest and its Impact on Livelihood of Rural People, A Research Report submitted to IOF, Pokhara.

7. Upadhyay, M. (2064). Byabastit khoto sankalan- Jibikoparjan ko Bikalpa, Hamro Kalpabrikchha, 15(95): 19-22

8. Chaudhary, D.C (2000). Management of Pine Resin Tapping for Community Development: Technical paper presented in Regional workshop on "Community based NTFP Management"

9. Poudel, B. (2017). Contribution of Resin tapping to enhance in economic condition of local people, a case study from Rukum district.

10. Subedi, L. P. (2010). Employment opportunity from Resin Tapping in Nepal. Ganapati Rosin and Turpentine Pvt. Ltd, Nepal on http://www.forestrynepal.org/images

11. Karki, I. S., \& Tiwari, S. (1998). Towards Sustainable Management of Forests: Learning from the Experiences of Community Forest in Nepal 51-65. Livelihood. 